\title{
Challenges Faced by the Kenya Water Sector Management in Improving Water Supply Coverage
}

\author{
Chemeril Chepyegon, Daisuke Kamiya \\ Department of Civil Engineering, University of the Ryukyus, Nishihara, Japan \\ Email: chemerilc@yahoo.co.uk,d-kamiya@tec.u-ryukyu.ac.jp
}

How to cite this paper: Chepyegon, C. and Kamiya, D. (2018) Challenges Faced by the Kenya Water Sector Management in Improving Water Supply Coverage. Journal of Water Resource and Protection, 10, 85-105. https://doi.org/10.4236/jwarp.2018.101006

Received: December 20, 2017

Accepted: January 28, 2018

Published: January 31, 2018

Copyright (๑) 2018 by authors and Scientific Research Publishing Inc. This work is licensed under the Creative Commons Attribution International License (CC BY 4.0).

http://creativecommons.org/licenses/by/4.0/

\begin{abstract}
Water is an important component in national development. Despite the efforts of the Kenyan government to increase water coverage throughout the country so that economic development of the nation remains unimpeded, recent statistics show that the rate of water supply improvement is unlikely to support the nation's long-term development goals. This paper examines literature, reports, studies and other relevant information regarding Kenya's water sector in order to expose the underlying causes of the challenges the sector management faces. It also analyses the interrelationships between the challenges and discusses opportunities for improvement. From the study, nine root causes of the challenges that are of technical, economic and social in nature were identified. As they evolve, they conjoin into other problem scenarios characterised by: unsustainability of water supply systems, low social acceptance of interventions, low investment in the sector and water-related conflicts. It is also observed that the sector management has opportunity for improving the current situation through adoption of elaborate monitoring strategies for water services and water resources, embracing sustainable technologies and involving target beneficiaries in water supply development. Great strides can be achieved by the sector through Adaptive Management (AM).
\end{abstract}

\section{Keywords}

Water Sector Management, Water Coverage, Water Challenges, Water Supply Improvement, Adaptive Management, Kenya

\section{Introduction}

The government's drive to improve water services in Kenya started in 1967, two 
years after independence, when basic facilities amongst the water and sewerage were nationalised to allow government to provide and expand services so as to spur development for improved welfare of its citizens. It is reported that Kenya had achieved high urban water supply service coverage by 1970 [1] and that the focus then shifted to rural areas with the goal of reaching all the rural population before the year 2000 [2]. This was not to be as the rural-urban migration strained services in urban areas [1], forcing the government to re-strategize its long-term water targets. Even then the targets remained elusive: the government was not only encountering hurdles in expanding water infrastructure but also facing sustainability issues from existing systems. This situation prompted the commencement of reforms in the sector which led to the adoption of a new water policy in 1999. The policy was founded on principles of separation of regulatory functions from actual service provision in order to improve service delivery [3]. In line with the new policy, new water laws were enacted in 2002 in which the management of water resources and water services was separated, and the role of the central government was decentralised to semi-autonomous government agencies. Since the roll out of new water laws in 2004, improvement in delivery of water services, more so in urban areas, has been observed; for example the positive response from respondents in a joint survey done by civil society organisations in Kenya's main cities [4]. However, the sector continues to face challenges. The water targets especially in rural coverage are not being met. In the National Water Services Strategy, the government aimed at achieving $80 \%$ access to safe and reliable water for urban areas and $75 \%$ for rural areas by 2015 [5], but it managed $82 \%$ and $57 \%$ respectively [6]. Table 1 shows water coverage as reported by Kenya National Bureau of Statistics (KNBS) [7] [8] [9] and the United Nation's (UN) Joint Monitoring Programme (JMP) [6]. Both JMP's and KDHS' estimates were higher than the actual meaning that there exists a real possibility that any latest working estimates may be overstated.

The world's 2015 Millennium Development Goal (MDG) target of $88 \%$ access to improved drinking water source was achieved in 2010 [6]. 147 countries met the target leaving close to a quarter of the world nations (24\%), including Kenya, below the global MDG target. Although Kenya recently graduated from the list of Least Developed Countries (LDCs) ranking by the UN, its water coverage as at 2015 (63\% in the JMP report) was lower than both the LDCs' average of 69\%, and Sub-Saharan Africa average of $68 \%$. According to the water supply statistics data presented by [6] for 2015, the Kenyan portion of people without safe drinking water is close to $3 \%$ of the global figure. In comparison to neighbouring Uganda which had similar water coverage two decades ago at the advent of water reforms in both countries, Kenya's water coverage remained sluggish after the reforms despite its economy being double that of its neighbour but with comparable size of population and land area. There are convincing reasons to believe that Kenya should have met its water targets including those of the MDG.

In 2007 the government of Kenya rolled out The Kenya Vision 2030 which is an ambitious development plan that aims to transform the country into a middle 
Table 1. Water coverage in Kenya.

\begin{tabular}{ccc}
\hline Information Source & 2009 & 2014 \\
\hline KNBS [in Kenya Demographic Health and & 60.2 & 66.9 \\
Surveys (KDHS) report] $^{\mathrm{a}}$ & 59 & 63 \\
JMP $^{\mathrm{a}}$ & 52.6 & - \\
\hline KNBS (national census) & $\mathrm{b}$ & \\
\hline
\end{tabular}

a. Estimates; b. Actual.

income country by 2030 by improving economic, social and political sectors. The plan acknowledges the pivotal role of water in the growth of economic and social sectors as the country gets industrialised and more urbanised. In that regard the plan anticipates a universal access to water by 2030, which is apparently congruent with UN's 2030 Sustainable Development Goals on water and sanitation. In addition to the water needs contained in the plan, the Kenya constitution promulgated in 2010 further treats the enjoyment of clean and safe water in adequate quantities by every Kenyan citizen as a basic right. The increased water requirement therefore demands great efforts from the Kenya water sector management in water resources conservation and water services development.

It is clear that challenges facing the water sector, ranging from water scarcity, water quality, population pressure, climate change, among others, are shared globally and the role of water sector management in confronting the challenges cannot be underestimated. In order for Kenya to meet its 2030 development agenda, the water problem is one of the issues that need to be addressed. [10] observed that little research work has been done to uncover the challenges facing the Kenyan water sector. Articulation of the sector's challenges is one of the starting points in the problem solving process. Towards this cause, this paper examines literature, reports, studies, reviews and other relevant information regarding Kenya's water sector management in order to expose the underlying causes of the challenges that the sector faces, and analyses the interrelationships between the challenges. In order to gain an understanding of the challenges, background information including management set up of Kenya's water sector, water resources management and water services provision are described. The paper further examines opportunities for improvement in the current water sector dispensation, and solution proposal.

\section{Water Sector Management in Kenya}

\subsection{Management Structure}

The water sector in Kenya is managed as per the Water Act 2002. Ministry of Water and Irrigation (MWI) heads the sector with the role of policy formulation, planning and resource mobilisation. There are national, regional and local institutions under the MWI (see Figure 1) that operate with some level of autonomy. The aim is to cut down bureaucracy and improve performance and efficiency in service delivery. The ministry discharges its mandate in two ways: 


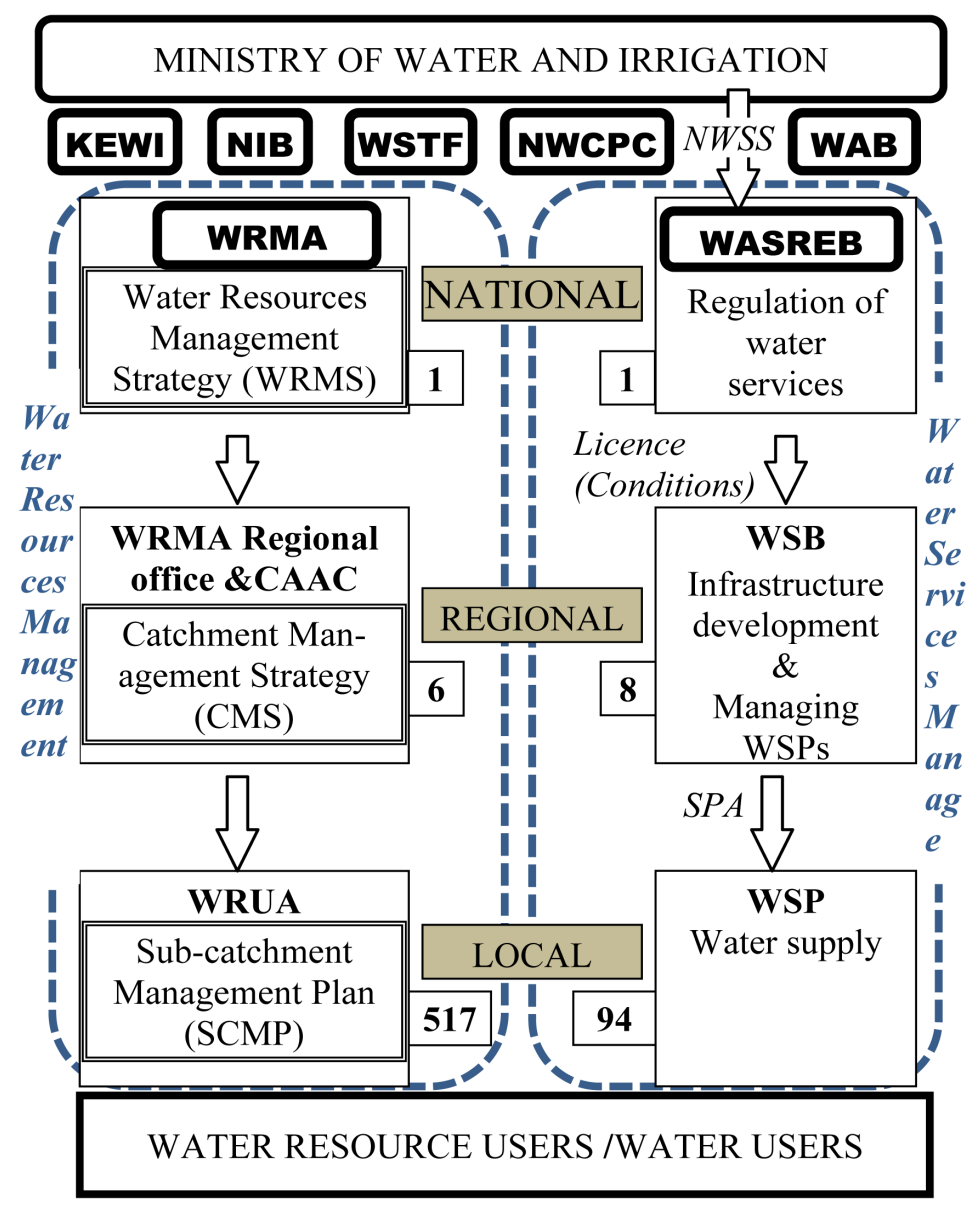

Figure 1. Kenya's water sector management structure (A new legislation was enacted in September 2016 necessitated by promulgation of a new constitution which transfers provision of water services to county governments. There are no fundamental changes in the management structure).

water resources and water services, both of which are managed separately but in a parallel manner. At national level the Water Resources Management Authority (WRMA) heads the water resources while Water Services Regulation Authority (WASREB) heads water services. At the regional level there are six WRMA regional units in water resources section and eight Water Services Boards (WSBs) in water services section. Their areas of operation are delimited based on basin boundaries of the main rivers. At the local level there are a total of 517 Water Resources User Associations (WRUAs) [11] under WRMA and 94 Water Services Providers (WSPs) under the WSBs [12].

There are other national institutions with specific national mandates as follows: Kenya Water Institute (KEWI) - carries out training and research; National Irrigation Board (NIB)-develops, improves and controls irrigation schemes; Water Services Trust Fund (WSTF)-finances pro-poor water and sanitation projects; National Water Conservation and Pipeline Corporation (NWCPC) - constructs water storage facilities and drills boreholes; Water Appeal Board (WAB) - arbitrates water-related disputes and conflicts. 


\subsection{The Nation's Water Resources and Their Management}

\subsubsection{Water Resources}

Kenya's natural renewable water resources heavily depend on the few and fragile catchments covered by montane forests in the country's highland areas where humid climate zone is prevalent. They are the headwater catchments of Kenya's main rivers that make up the five basin areas in the country namely: Lake Victoria, Rift Valley, Athi, Tana and Ewaso Ng'iro North (Figure 2 \& Figure 3). It is estimated that the catchments contributes over $75 \%$ of the nation's surface water resources [13]. Table 2 shows the condition of the main catchments with information collated from [14] [15] [16]. The dilemma facing the government has been to balance between the expanding agriculture, which thrives in the region of the catchments and supports the country's economy, vis-a-vis conserving the forests [17].

\section{KEY:}
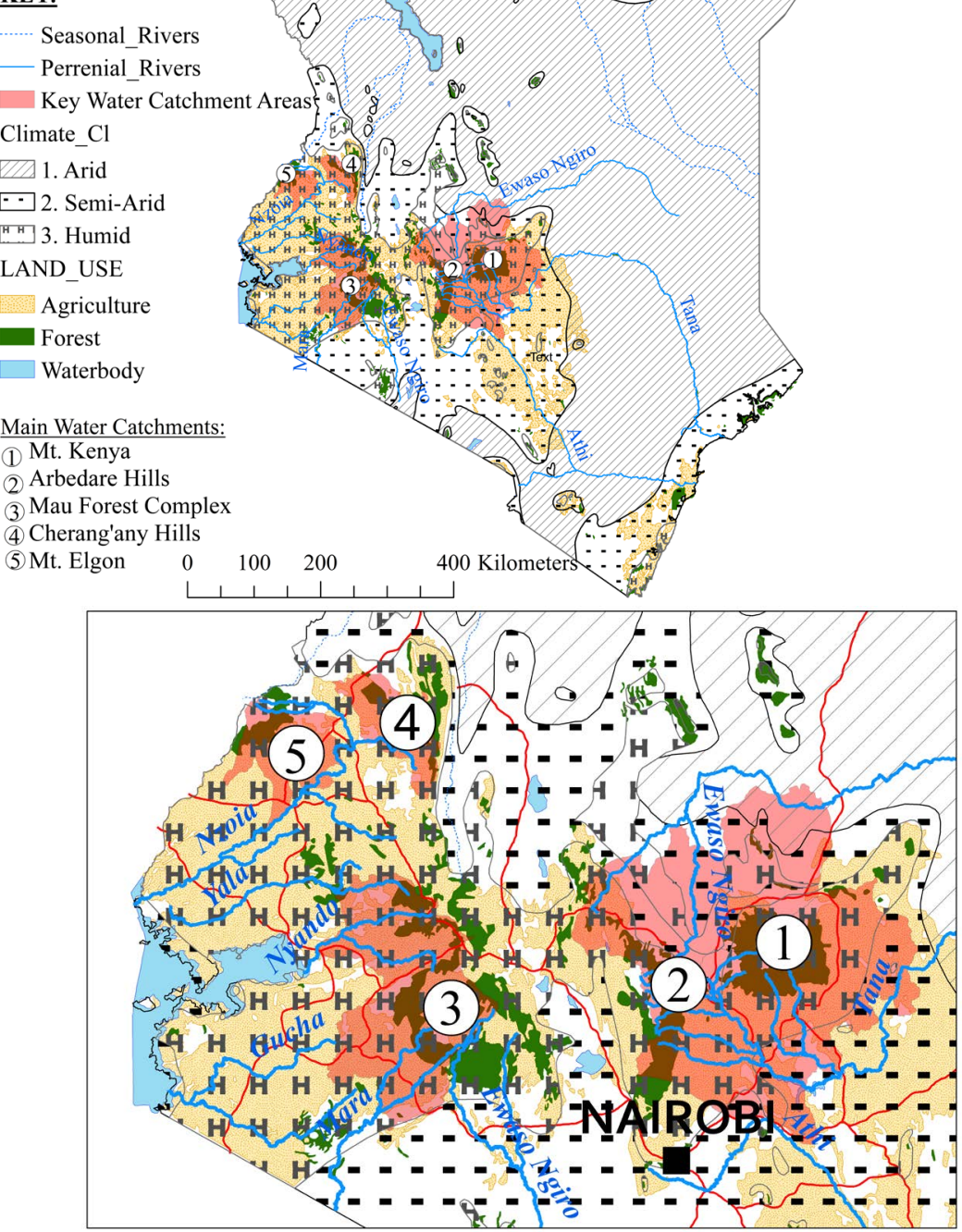

Figure 2. Main water catchment areas of Kenya. 


\section{KEY: \\ - Main_Cities \\ - Main Rivers \\ Waterbodies}

\begin{tabular}{|c|c|c|}
\hline \multicolumn{3}{|c|}{$\begin{array}{l}\text { Water_Demand_vs_Water } \\
\text { Resources Ratio (\%) }\end{array}$} \\
\hline & 10 & 2030 \\
\hline Lake Victoria: & 6 & 39 \\
\hline Rift Valley: & 14 & 47 \\
\hline Ewaso Ng'iro: & 9 & 95 \\
\hline Tana: & 14 & 105 \\
\hline Athi: & 76 & 281 \\
\hline
\end{tabular}

$\begin{array}{lllll}0 & 62.5125 & 250 & 375 & 500\end{array}$

Source: Kenya National Water Master Plan 2030

Figure 3. Water basins and water balance in Kenya.

Table 2. Condition of main water catchment areas in Kenya.

\begin{tabular}{ccccc}
\hline Watershed name & $\begin{array}{c}\text { Catchment area }^{\mathrm{a}} \\
(\mathrm{ha})\end{array}$ & $\begin{array}{c}\text { Max. altitude }^{\mathrm{b}} \\
(\mathrm{m})\end{array}$ & $\begin{array}{c}\text { Gazetted forest area }^{\mathrm{c}} \\
(\mathrm{ha})\end{array}$ & Main river $^{\text {M. Kenya }}$ \\
Mt,253,959 & 5199 & $\begin{array}{c}203,145 \\
(4 \% \text { cropland }) \\
104,078\end{array}$ & Tana, Athi \\
Aberdare & $1,097,895$ & 4001 & $\begin{array}{c}11 \% \text { cropland }) \\
404,706\end{array}$ & Ewaso Ngiro, Athi \\
Mau Forest Complex & 874,746 & 3098 & $\begin{array}{c}(25 \% \text { cropland }) \\
120,841\end{array}$ & $\begin{array}{c}\text { Mara, Nyando, } \\
\text { Yala }\end{array}$ \\
Cherang'any Hills & 212,267 & 3365 & $\begin{array}{c}(19 \% \text { cropland }) \\
72,547\end{array}$ & Nzoia, Turkwell \\
Mt. Elgon & 249,996 & 4320 & $(15 \%$ cropland $)$ & Nzoia, Turkwell \\
\hline
\end{tabular}

a. [14]; b. [15]; c. [16].

Kenya's surface water resources is estimated to be 22,564 million $\mathrm{m}^{3}$ representing $91.5 \%$ of the total available water resources, the rest is groundwater [14]. As of 2010, the annual water demand was $14 \%$ of the available water resources; groundwater supplied $16 \%$ of the demand. Nearly $50 \%$ of the demand was from irrigation sector despite being for only $17 \%$ of the potentially irrigable land [18]. Scarcity of water coupled with low investment has been blamed for the low irrigation development in Kenya [19].

Information on Kenya's groundwater resources is limited because extensive groundwater survey has not been done [20]. Furthermore, despite Kenya sharing an estimated $54 \%$ of its water resources with neighbouring countries, the state of the water resources within the shared basins and the probable future demands by neighbour countries has not been established, neither has operational trans- 
boundary water law been legislated [11] [21].

As at 2010, Kenya's available freshwater resources index was estimated to be $1093 \mathrm{~m}^{3} /$ capita/year while water resources availability was $586 \mathrm{~m}^{3} /$ capita/year [14]. In global context, it has been argued that when annual per capita renewable water resources availability is below 1,000 cubic meters, water scarcity begins to hamper economic development and human health and well-being [22]. However, the discovery of a historic $250,335 \times 106 \mathrm{~m}^{3}$ (equivalent to 70 -year national water demand) water storage aquifer in north-western Kenya in 2013 drastically improves the water security situation of Kenya and is estimated to increases per capita water resources availability by $17 \%$ [23].

\subsubsection{Management}

WRMA is the national lead organisation that manages allocation of water resources to various users, determines conditions for water use permit and related charges, plans for conservation of water resources and maintains water resources data. It develops the National Water Resources Management Strategy (NWRMS) which outlines the strategy with which its mandate will be achieved [3].

At each of the six regional (catchment) levels there is WRMA regional office and Catchment Area Advisory Committee (CAAC). In consultation with CAAC, WRMA regional office develops a Catchment Management Strategy (CMS) consistent with NWRMS [3]. Further within each region, there are several Water Resource Users Associations (WRUAs) that are based at sub-catchment level. WRUAs prepare a Sub-Catchment Management Plan (SCMP) in line with the region's CMS. SCMP describes the water resource management problems within a sub-catchment and a set of prioritised activities for addressing them.

\subsection{Management of the Water Services Sector}

Figure 4 is a representation of the management model for water services sector in Kenya. The MWI sets out the strategy of the water services sector through the National Water Services Strategy (NWSS) outlining current extent of services and an investment plan to reach underserved areas [3]. In order to increase water supply coverage levels, the MWI plans and constructs water (and sanitation) facilities through the WSBs, develops dams and boreholes through NCPWC, and implements water facilities aimed at the poor through WSTF.

The WSBs assumes ownership of all implemented facilities and leases them to Water Service Providers (WSPs) to run and manage them by supplying water, issuing bills and receiving revenues. The WSPs then use the collected revenue to (refer Figure 4):

1) manage their operations,

2a) pay lease fees to WSB,

2b) pay regulatory fees to WASREB,

2c) pay abstraction fee to WRMA,

3) service debts in instances where the MWI borrowed loans for developing water facilities that they run. 

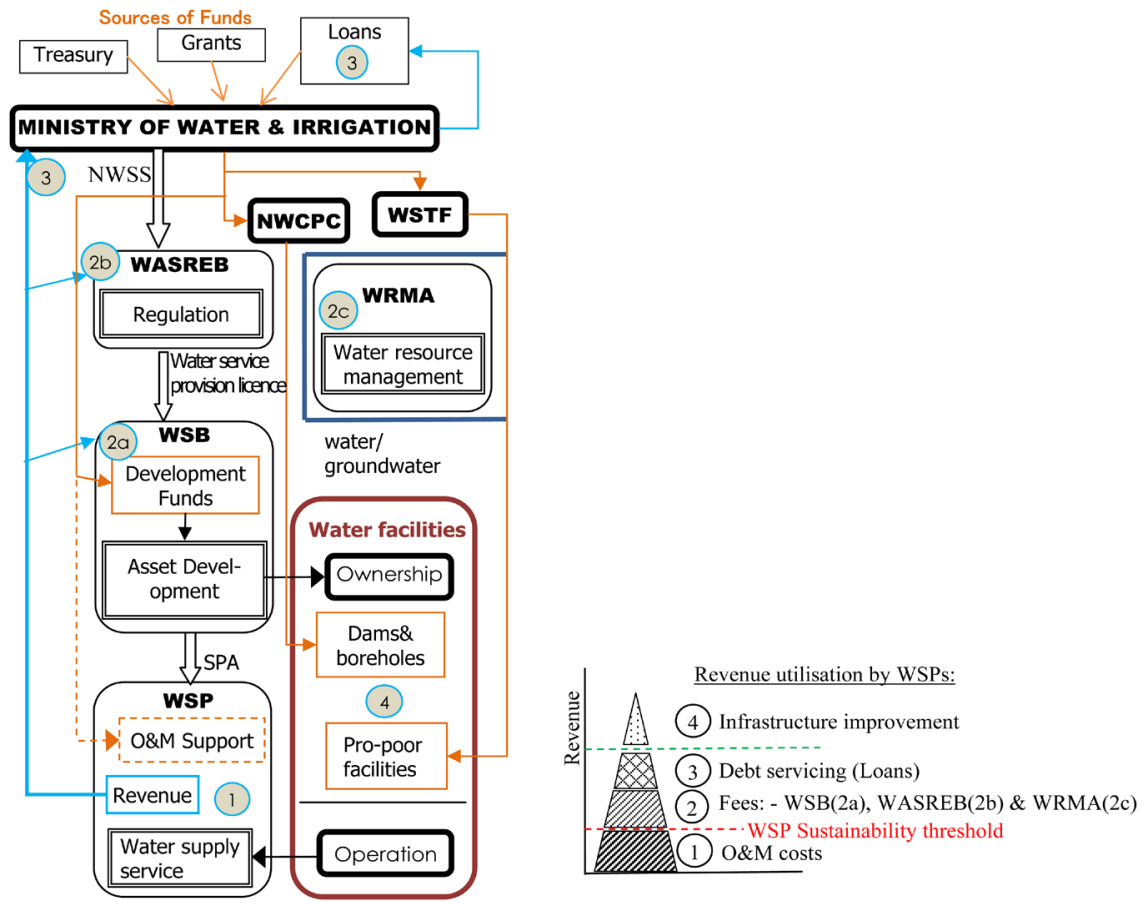

Figure 4. Current management model of water services in Kenya.

4) invest in system rehabilitation and expansion from any revenue remaining after fulfilling all the obligations above [24].

The ministry's underlying concept in this system was to commercialise the water services sector in order to improve efficiency in service provision and limit dependence on central government financing. Therefore for the WSPs whose revenues do not meet operation and maintenance $(\mathrm{O} \& \mathrm{M})$ costs, the MWI has been trying to cluster them to improve prospects of commercial viability [25]. In the meantime they receive support from MWI.

The law also provides for private water providers but their occurrence in reality is very minimal. WASREB reported of two private water service providers in their 2014-2015 report [12].

WASREB sets the regulations governing water services provision including service standards and tariff guidelines in line with the goals of NWSS and passes to WSBs in form of a licence, who then ensures WSPs adhere to these guidelines by entering into a Service Provision Agreement (SPA) with the WSPs.

\section{Water Services Provision in Kenya}

The MWI approach to water services is mainly twofold: urban (including the urban poor) and rural, which both have different characteristic set ups as highlighted in Table 3.

\subsection{Current Water Coverage}

Nationally, water supply coverage obtained from 2009 national census stood at $52.6 \%$ (Table 4) [8]. Urban areas had more coverage (71.7\%) compared to rural 
Table 3. Main characteristics of urban and rural water users in Kenya.

\begin{tabular}{cccc}
\hline Category & \multicolumn{2}{c}{ Urban } & Rural \\
\hline Feature & Urban poor & Urban, other & \\
Geographical location & Urban & Urban & Rural \\
Population density & Very dense & Dense & Sparse to very sparse \\
Socio-economic status & Very poor & Medium to wealthy & Poor to wealthy \\
Main sources of water & $\begin{array}{c}\text { Water kiosks, water } \\
\text { vendors }\end{array}$ & $\begin{array}{c}\text { Piped systems to } \\
\text { houses, yard taps }\end{array}$ & $\begin{array}{c}\text { streams, borehole, wells, springs } \\
\text { \& small-scale piped systems } \\
\text { Main water operator }\end{array}$ \\
$\begin{array}{c}\text { Formal WSP, water } \\
\text { vendors }\end{array}$ & Formal WSP & $\begin{array}{c}\text { Informal WSP } \\
\text { individual/community }\end{array}$ \\
\hline
\end{tabular}

Table 4. Access to water by households by type of source in Kenya in 2009 (\%).

\begin{tabular}{|c|c|c|c|}
\hline Source & Overall & Urban & Rural \\
\hline Stream/River & 23.2 & 9.2 & 29.6 \\
\hline Unprotected Well & 6.9 & 2.9 & 8.7 \\
\hline Water vendor & 5.2 & 11.8 & 2.2 \\
\hline Unprotected Spring & 5.0 & 1.9 & 6.4 \\
\hline Pond & 2.7 & 0.9 & 3.6 \\
\hline Dam & 2.4 & 0.7 & 3.2 \\
\hline Lake & 1.2 & 0.5 & 1.5 \\
\hline Jabia & 0.3 & 0.2 & 0.4 \\
\hline Other & 0.4 & 0.1 & 0.5 \\
\hline Total Unimproved Sources & 47.4 & 28.3 & 56.0 \\
\hline Piped (shared/yard tap) & 19.2 & 34.9 & 12.1 \\
\hline Borehole & 11.6 & 10.7 & 12 \\
\hline Protected Well & 7.7 & 6.8 & 8.1 \\
\hline Protected Spring & 7.6 & 4 & 9.2 \\
\hline Piped into Dwelling & 5.9 & 14.7 & 1.8 \\
\hline Rainwater Collection & 0.7 & 0.5 & 0.8 \\
\hline Total Improved Sources & 52.6 & 71.7 & 44.0 \\
\hline TOTAL & 100 & 100 & 100 \\
\hline
\end{tabular}

areas where more than half of the households (56\%) obtained water from unprotected sources. The data shows that piped water (i.e. piped \& piped into dwelling) is the main source of water for urban residents while streams/rivers is the main source for the majority in rural areas (29.6\%). Groundwater provided water to approximately one-quarter of Kenyan households.

Water use patterns also differ between urban and rural Kenya. The study done by [26] showed that approximately $85 \%$ of household water is used for cooking, drinking, washing and bathing. However, urban dwellers tend to use about twice as much water as rural residents and households with piped connections (major- 
ity in urban areas) use, on average, three times more water than those without. This can be partly attributed to the high unit cost of water arising from poor water supply services in rural areas as concluded in the study done by [27].

\subsection{Urban Water Situation}

Water services in urban areas are provided by urban WSPs. All urban WSPs are under formal regulation by WASREB (refer Figure 4). WASREB is therefore able to track and report on these WSPs. Table 5 below shows the status for 86 urban WSPs as reported in WASREB's latest report for 2014/15 period. From the table, it can be seen that water coverage, NRW and metering ratio are below the standards set by WASREB. The average O \& $\mathrm{M}$ cost coverage is $99 \%$ implying that most urban WSPs are able to meet their operation and maintenance costs from the revenues generated and therefore require no $\mathrm{O} \& \mathrm{M}$ support from the government.

Providing water services in informal settlements in urban areas of Kenya is greatly hampered by planning challenges due to densification of unplanned structures. This leaves water kiosks as the preferred means of serving the urban poor, howbeit accessibility cannot be ascertained. Basic access is defined by [28] as 20 litres per person per day. A recent review by [29] on the state of urbanisation in Kenya however observed that water supply service hours in informal settlements (urban poor) are comparable to those in formal implying that there is equitable water supply distribution in most urban areas of Kenya.

Table 5. Performance of Kenyan urban WSPs in 2014/15.

\begin{tabular}{|c|c|c|}
\hline General & & \\
\hline Urban WSPs (count) ${ }^{\mathrm{a}}$ & 86 & \\
\hline Urban centres served (count) & 132 & \\
\hline Total population in WSP area (million people) & 20.38 & \\
\hline Population served (million people) & 11.12 & \\
\hline Average consumption (litres/capita/day) & 43 & \\
\hline Indicators & $2014 / 15$ average & Minimum recommendation \\
\hline Water coverage, population (\%) & 55 & $>80$ \\
\hline Water quality-compliance with standards (\%) & 92 & $>90$ \\
\hline Hours of supply (hours/day) & 18 & $>12$ \\
\hline Non-Revenue Water, NRW (\%) & 43 & $<25$ \\
\hline Metering Ratio (\%) & 90 & $>95$ \\
\hline $\begin{array}{c}\text { Staff productivity } \\
\text { (number of staff per } 1000 \text { connections) }\end{array}$ & 7 & $<14$ \\
\hline Personnel expenditure as \% of O \& $\mathrm{M}$ costs (\%) & 42 & $<45$ \\
\hline O\&M cost coverage (\%) & 99 & 100 \\
\hline
\end{tabular}

a. Total urban WSPs $=94$, WASREB could not report 8 due to lack of information. 


\subsection{Rural Water Situation}

Rural areas are characterised by dispersed settlements thus making it costly to invest in piped water systems. Majority of the water sources are therefore point sources. It is estimated that $40 \%$ of the households in rural areas of Kenya use more than 30 minutes for round trip to obtain drinking water from source [7]. The condition is presumably worse for the arid and semi-arid areas where there are fewer water sources. As seen in Table 4, 56\% of rural water sources are unimproved, implying that over half of rural population depend on natural processes and homemade solutions to treat water for drinking.

Facilities developed in rural areas are normally handed over to the concerned community groups after installation, and they are expected to meet operation and maintenance costs from the revenues they generate from water sales. Water service connections for almost all rural consumers are not metered and they are billed on a flat rate every month. The revenues collected by the managing committee therefore barely covers operation costs, thus requiring WSB's periodical assistance especially during major maintenances [30]. Apart from the periodical technical assistance, the WSBs other mandate is to build the capacity of the water supply management committee to enable them to manage the water facilities.

The small economies of scale make it seldom feasible to commercialise rural water services. Faced with this challenge, the MWI has adopted "community-based and demand-driven but open for commercialisation wherever possible" approach to rural water supplies in its national strategy [5]. For the meantime there's less formal monitoring and regulation of rural water supplies.

In the areas where no WSP has been identified, water services are operated by WSBs on an interim basis, or provided by associations. Other institutions like churches also construct small scale facilities and provide support to the respective communities in running and managing the facilities [25].

\subsection{Pro-Poor Strategy in Water Services Provision}

Close to half of Kenya's population (45.9\% in 2006-[18]) is considered poor and more than three-quarters of them (79\% in 2006-[18]) live in rural areas. Recently, there has been focus on improving water coverage to the poor in Kenya emanating from the need to reach more people in order to justify investments in the sector, and the entrenchment of access to water as a basic right for every Kenyan citizen.

The MWI, through the WSTF, has established two main systems for accessing and using funds for water and sanitation projects in the poorest and underserved locations of Kenya: Rural Investment Programme for projects targeting the rural poor and Urban Investment Programme for projects targeting the urban poor. Under Rural Investment Programme, the Community Project Cycle (CPC) system was the first to be rolled out in 2007 and has resulted in commendable gains albeit on a small scale [31]. The Urban Investments Programme targets the urban poor who live in low-income areas within the jurisdiction of formal regu- 
lated WSPs. In addition to direct investment targeting, WASREB also regulates water tariffs based on household income to protect consumers, including the poor, against overpricing [28].

The MWI also developed Pro-Poor Implementation Plan for Water Supply and Sanitation (PPIP - WSS) which is tailored to ensure that the sector lays emphasis on the poor in its water development agenda. To achieve this, the strategies in the plan include adjusting the current policies and legislations to be pro-poor, emphasising on low cost technologies, formal regulation of water service provision countrywide and a distinction in approach between rural and urban water provision. However, no information or report was obtained regarding the progress of this plan.

\section{Key Challenges Faced by the Kenyan Water Sector Management}

\subsection{Operation and Maintenance Challenges Emanating from Initial Choice of Intervention and Poor Management Practices}

Most urban WSPs are able to meet their O \& M costs owing to their large economies of scale. The situation however is different for rural water supplies; up to 25 per cent fail within 5 years of age primarily due to operation and maintenance issues [32] [33]. The lack of favourable conditions to implement commercialisation leaves the management of most rural water supplies under community based organisations. In most instances there are no adequate skills within the community to manage the facilities professionally, and this may be coupled with the unavailability of spare parts within the locality [34]. Thus the sustainability of rural water facilities is highly sensitive to choice of intervention. The findings of survey done by [32] in one rural part of Kenya showed that $94 \%$ of the respondents agreed that the choice of technology influenced the sustainability of their water supplies. The MWI acknowledges this challenge and its strategy is to entrench participatory processes in order to implement sustainable technologies [5]. Currently there are no strict technical standards in the sector to save the situation [33] [34]. The study by [33] assessing 100 community projects implemented across Kenya found out that $59 \%$ of them had varying levels of dysfunctionality attributable mainly to design aspects and maintenance issues. Another case of design deficiency is reported by [35] where per capita consumption of water assumed during design stage turned out to be lower than actual.

Community managed projects are also prone to mismanagement by managing committees because they are less monitored by WASREB. Distrust between community and the management team on issues centring around transparency and accountability normally arise, for example the cohesion problems reported in Kisayani community by [35]. Malpractices such as poor control of finances, lack of transparency, over employment, etc. are often reported (e.g. [1]) and they are the main sources of disintegration between the management committee and the community. In the end, such problems lead to revenues being spent in mat- 
ters that are not of priority as regards the sustenance of the water facilities. The MWI plan against this in its current strategy is to enforce regulation [5]. However, enforcing regulation hinges on the rural sub-sector being brought under formal monitoring and regulation by WASREB, which has yet to be fully implemented. The urban WSPs on the other hand have varying levels of adherence to principles of good governance [12]. The general observation by [36] from past case studies reveals that WPSs with higher level of adherence to corporate governance have higher performances in service delivery. Costs associated with pumping systems are also reported to be the main cause of concern in urban water supplies as it forms bulk of $\mathrm{O} \& \mathrm{M}$ costs, thus leaving water utility companies in dire financial straits [14]. Because of this, the sector has been emphasizing on gravity systems in recent times [5].

Relative high cost of $\mathrm{O} \& \mathrm{M}$ compared to revenue makes it difficult for water service providers to carry our routine maintenance and to hire and retain competent staff due to insufficient revenue [5]. This leads to slow decay of infrastructure [33] and consequently a decrease in the number of consumers served [37] and a decline in quality of services [5], which then results in a falling revenue generation [5] [33] [37]. In the urban setting or piped systems, and in the event that the water loses are incurred due to decaying infrastructure, then the downward cyclic trend is greatly exacerbated by Non-Revenue Water (NRW) [14] [37].

\subsection{Inadequate Funding of the Sector and Disproportionate Funding within the Sector}

The level of funding of the water sector is below the level required to meet the growing demand for water. Annual budget for the sector is approximately $2.8 \%$ of the national budget, which is estimated to cover around $44 \%$ of the required investment cost [14]. The resulting funding gap is partly financed by donors. Donor financing in the ministry ranged between $55 \%$ - $65 \%$ of the ministry's total annual budget in 2010-2014 period. Pro-poor fund managed by WSTF ranged between $1 \%$ to $3 \%$ of the ministry's annual budget in $2005-2010$ period [14]. This implies that allocation to poor areas is low. This can be partly attributed to the borrowing of funds (to meet investment gap) which makes return on investment a priority factor in investment targeting process. Therefore poor areas with low Ability to Pay (ATP) and Willingness to Pay (WTP) receive a lower priority. This problem has been linked to the commercialisation of water services which has generated a wide discussion globally. While the basis of commercialisation is improvement of service delivery, many have argued that the eventual outcome is biased against low-income earners, thus violating the basic right to water [25] [38]. For example, [30] observed that upon enactment of procommercialisation reforms in Kenya, commercialisation drive spontaneously picked up fast in urban areas compared to rural owing to the disparity in incomes and willingness to pay. National statistics show that urban residents have 
1.5 to 2 times more access to an improved water source than their rural counterparts [8]. In the Kenyan context therefore, there are reasons supporting the argument that commercialisation of water services has ended up favouring urban areas. In fact established WSPs can access commercial loans to expand services within their areas of operation if their financial and operational status is robust [39]. This is in contrast to rural areas where forming a viable WSP still remains a challenge.

Water resources conservation is also severely underfunded. This is despite the persistent water crisis that has been attributed to environmental destabilisation [14] [40]. As the effects of climate change is also predicted to increase the intensity and frequency of flood-drought cycle in Kenya, the low adaptability by the sector management due to insufficient funds is projected to decrease water quality and lower water resources availability in the country [41]. While allocation of funds to the water resources sub-sector is one challenge, inefficiencies and bloated staff within the sub-sector itself has been pointed out by the parent ministry [42]. Unlike water services, the sub-sector has not been able to generate enough revenues to sustain its operations [42]. The parent ministry is thus obligated to continue supporting it to meet its operational expenses thereby straining financial resources that could have been allocated for conservation activities. Nevertheless the greatest undoing currently due to lack of financial resources is the inadequate monitoring of water resources because it hampers the planning and management of water resources which has yet to expand beyond national waters to transboundary waters [1] [43].

Inadequate funding for water conservation measures leads to gradual decline in quality and quantity of water from the sources [42] [44]. Irrigation, being the main consumer of water, is thus gravely affected [40]. Water quality deterioration due to catchment degradation makes it expensive to treat water for industrial and domestic consumption, and to maintain water facilities and reservoirs, thus increasing $\mathrm{O} \& \mathrm{M}$ costs [41] [45].

\subsection{Low Social Acceptance of Interventions}

The problem of social acceptance is paramount in rural water supplies primarily because the communities are required to take over operation and maintenance of the facilities once construction is complete. Lessons learnt from the empirical study of [46] on rural water supplies in Kenya suggest that inclusion of community households from formative stages of water project, involving them in deciding service levels and in making capital cost contribution raises the sense of ownership. The problem of ownership can be deduced from the recounts by [1] where vandalism of water facilities was rampant in the years before 2000 when water facilities were developed and operated by government with little consultation with beneficiaries. Although little is enumerated and documented on Kenyan rural water supplies due to loose monitoring, there is general consensus that the lack of complete inclusion of local communities in all the project develop- 
ment stages leads to low acceptance of the projects, for example [21] [42] [47]. The success of $\mathrm{CPC}$-implemented projects has been attributed to the rigorous involvement of the beneficiary communities right from inception through planning up to implementation stage. Lack of sense of ownership of water projects by the beneficiary communities wanes their support for the projects, resulting in low social acceptance. This ends up in most projects stalling or getting sabotaged, thus dragging the improvement of water situation [1].

\subsection{Conflicts}

The fast growing population and the subsequent socio-economic development including urbanisation and industrialisation causes an increase in demand for water. With the country having uneven water resources distribution, conflicting interests arise amongst various water users. An example is the Tana River Basin where there are sporadic conflicts between competing upstream (irrigation and hydropower) and downstream (irrigation and livestock watering) uses [21]. It is reported that irrigated agriculture is not expanding chiefly due to limited amount of water resources despite the paradox of existence of food poverty (estimated at 48\%) [18] and availability of irrigable land [19]. Water Conflicts also arise between adjacent community groupings, especially in rural areas, for various social reasons. [47] mentions the recurring conflicts between two ethnic communities during dry seasons around the water-scarce Lake Naivasha area stemming mainly from the values ascribed to water: one community values water for farming, while the other for pastoralism. Ethnicity-related water conflicts, which have occasionally led to eruption of violence, have also been recorded, for example [1] [21] [47]. For urban water supplies, conflicts emerge from the installation of water facilities in the source area which in most cases is remote from the target service area. The residents living within the locality of the source area usually demand for consideration (including compensation) and equal treatment. In some instances it has led to series of court cases and injunctions, for example Thika dam water project [48]. Current examples include Nairobi's Northern Collector Tunnel project which is an inter-basin water transfer project affecting far neighbourhood of the city. Opposition to the project by the residents and leaders in the source area has made to the local news on several occasions. The same challenge is faced in Kenya's 2nd largest city, Mombasa, where Mzima water pipeline which serves the city conveys water from springs that are approximately $200 \mathrm{~km}$ away. Unresolved conflicts lead to collapse of water facilities [49].

\section{Conclusions}

The interrelationships of the challenges elaborated in the preceding section is summarised in Figure 5. It is found out that low irrigation development and low water service provision standards are the other resultant effects which share same set of challenges with low water supply coverage. 


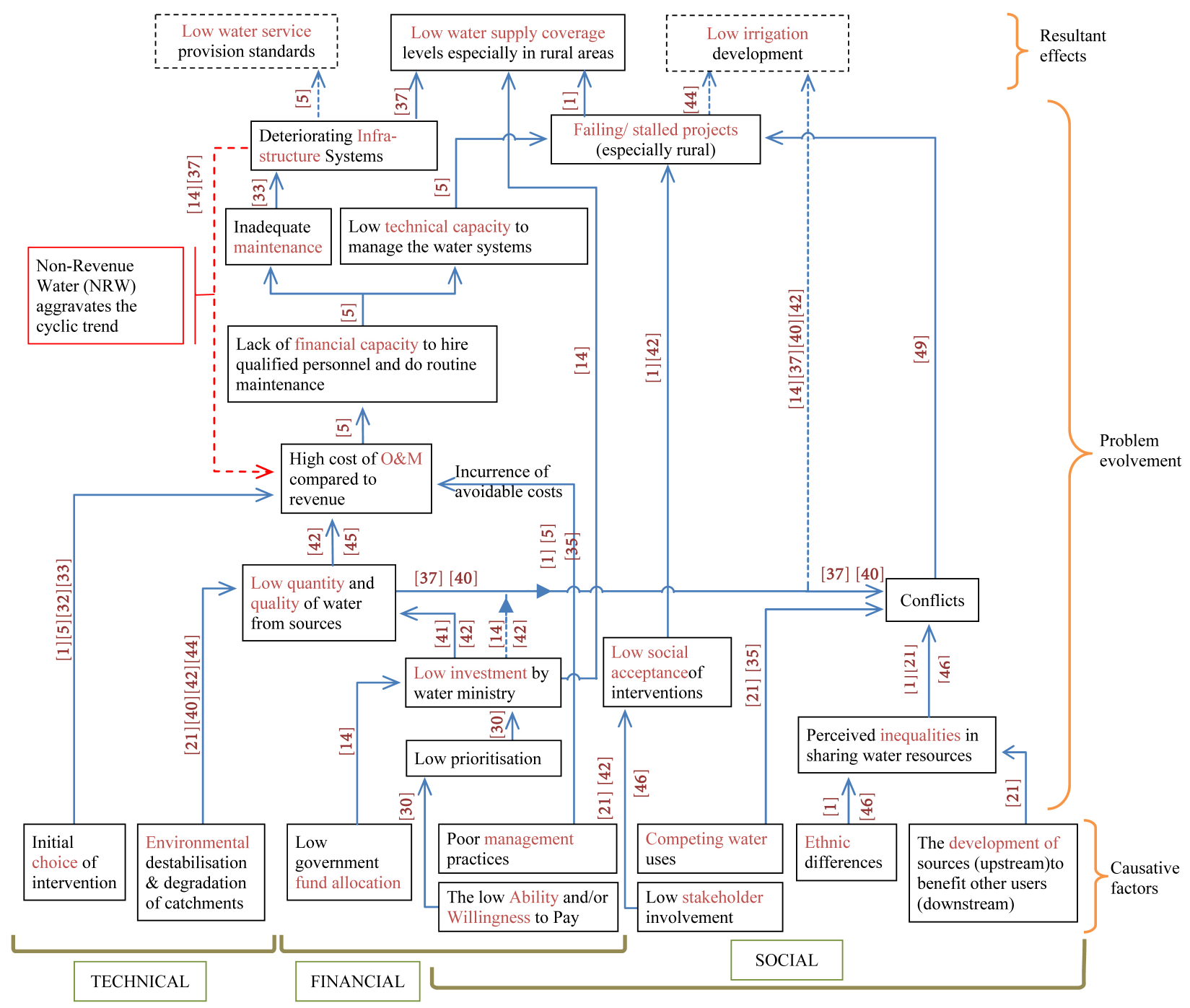

Figure 5. Diagrammatic representation of the challenges faced by Kenya water sector management in improving water supply coverage.

From the analysis, it is found out that the key root causes are: choice of water supply interventions, environmental destabilisation and degradation of catchments, inadequate funding of the water sector, poor management of water supplies, low ability and willingness to pay by the majority of the populace, low stakeholder involvement during water resources development, competing water uses, ethnic differences and unequal development of water resources. As these factors evolve, they conjoin into common interrelated higher order problems, which include: unsustainability of water supplies due to high operation and maintenance costs compared to revenue earnings, low investment in water sector, low social acceptance of interventions and conflicts.

It is observed that the legislation governing the sector is adequate in many respects save for the aspect of commercialisation of water services which lacks a mechanism for balancing urban and rural water supply improvement. This, by extension, has created a divide between the poor (majority of who live in rural 
areas) and those who can comfortably afford to pay for water services. Rural and urban-poor areas lag behind in water development. The lack of consistent monitoring of water supply services (especially in rural areas) by the sector management further complicates this case. An example is the problem of poor management of rural water supplies which remains largely unchecked. A replica of monitoring problem is also evident in the water resources sub-sector where the inadequate monitoring of the nation's water resources deprives the management of the vital information necessary for robust planning and management of conservation measures. There is therefore an urgent need to establish a monitoring strategy which would help the sector to rightly diagnose the challenges it faces and provide apt solutions.

The sector also lacks minimum technical standards for water facilities to be implemented in the country. This has occasionally resulted in developing facilities that are costly for water supply operators to run. In rural areas where most management committees are ill equipped with technical and managerial skills, such projects easily fail. Embracing research creates opportunity for creative ideas for sustainable interventions. Further, social problems have also led to failure of projects through conflicts and lack of social acceptance of interventions. The success of CPC-implemented projects, however, serves as a pointer to the importance of involving beneficiary communities in overcoming, to a good degree, technical and social challenges in water development. In this regard, it is recommended that the sector management expands (and/or adapts where necessary) the CPC approach sector wide.

In other developing countries, increasing water access to the poor is a prominent challenge faced by the water sector management [50], just as the case is shown for Kenya from this study. Social challenges like conflicts and low stakeholder involvement are similar across the developing world, which can be seen in Figure 5 that such challenges have less complex evolvement scenarios. On the other hand, the technical and financial challenges are more dependent on the interplay of many parameters in a given environmental setting including legislation and political set up.

Two management concepts have been put forward in addressing the challenges faced in the water sector: Integrated Water Resource Management (IWRM) and Adaptive Management (AM). Whereas IWRM is concerned with structure of approach to management of water resources, AM is designed to deal with uncertainties emanating from the complex nature of issues faced in resource management [51]. With the policies supporting IWRM in place, it is time for the Kenya water sector management to adopt AM to refine its management decisions towards a desired outcome. This may include a continuous review of performance of the sector and a cyclic national planning that is based on research and monitoring \& evaluation of the sector. The iterative process of planning-implementation-monitoring/evaluation/research-adjustment/improvemet will promote learning and better decision making leading to continuous improvement. 
In conclusion, the challenges facing the Kenya water sector management in improving water supply coverage are diverse ranging from technical, financial to social in nature. There sector management however, has opportunity for improvement through elaborate monitoring of water services and water resources, adoption of minimum technical standards for water supply facilities that ensures sustainability, and involving beneficiary communities in all stages of water supply development. Finally, adopting AM may solve the last puzzle by refining solutions to the raft of issues facing the sector management.

\section{References}

[1] Nyanchaga, E.N. (2016) History of Water Supply and Governance in Kenya (1895-2005) Lessons and Futures. Tampere University Press, Tampere. https://doi.org/10.26530/OAPEN_610992

[2] Danish International Development Agency (2010) Lessons Learned \& Good Practices from Support to the Kenyan Water Sector. Royal Danish Embassy/DANIDA, Nairobi.

[3] Water Act 2002 (2002) Government Printer. Nairobi.

[4] World Bank (2007) Citizen's Report Card on Urban Water, Sanitation and Solid Waste Services in Kenya: Summary of Results from Nairobi, Kisumu, and Mombasa. Working Paper No. 46304, World Bank, Washington DC.

[5] Ministry of Water and Irrigation (2007) The National Water Services Strategy (NWSS) (2007-2015). Ministry of Water and Irrigation, Nairobi.

[6] World Health Organisation and United Nations Children's Fund (2015) Progress on Sanitation and Drinking Water-2015 Update and MDG Assessment. UNICEF and World Health Organization, Geneva.

[7] Kenya National Bureau of Statistics (2015) Kenya Demographic and Health Survey 2014. Kenya National Bureau of Statistics, Nairobi.

[8] Kenya National Bureau of Statistics and Society for International Development (2013) Exploring Kenya's National Inequality-Pulling Apart or Pooling Together? Kenya National Bureau of Statistics and Society for International Development, Nairobi.

[9] Kenya National Bureau of Statistics and ICF Macro (2010) Kenya Demographic and Health Survey 2008-09. Kenya National Bureau of Statistics, Nairobi; ICF Macro, Calverton.

[10] Kibuika, F.M. and Wanyoike, D. (2012) Assessment of Factors Affecting Sustainability of Rural Water Supply Scheme in Nyandarua County Kenya: A Case of Kangui Water Scheme. International Journal of Science and Research, 3, 578-584.

[11] Water Resources Management Authority (2015) Strengthening Regulations for Sustainable Water Resources Management in Kenya. Water Resources Management Authority, Nairobi.

[12] Water Services Regulatory Board (2016) Impact Issue No. 9, A Performance Review of Kenya's Water Services Sector 2014-2015. Water Services Regulatory Board, Nairobi.

[13] United Nations Environmental Programme (2012) The Role and Contribution of Montane Forests and Related Ecosystem Services to the Kenyan Economy. UNEP, Nairobi.

[14] Ministry of Environment, Water and Natural Resources (2013) The National Water 
Master Plan 2030. Ministry of Environment, Water and Natural Resources, Nairobi.

[15] Kenya National Bureau of Statistics (2015) Statistical Abstract 2015. Kenya National Bureau of Statistics, Nairobi.

[16] Kenya Water Towers Agency (2015) Kenya Water Towers Status Report. Kenya Water Towers Agency, Nairobi.

[17] Ministry of Lands (2010) National Land Use Policy-Concept Paper. Ministry of Lands, Nairobi.

[18] Kenya National Bureau of Statistics (2007) Basic Report on Well-Being in Kenya. Kenya National Bureau of Statistics, Nairobi.

[19] Ministry of Water and Irrigation (2009) Water Sector Strategic Plan (WSSP) 2009-2014. Ministry of Water and Irrigation, Nairobi.

[20] Pavelic, P., Giordano, M., Keraita, B., Ramesh, V. and Rao, T. (2012) Groundwater Availability and Use in Sub-Saharan Africa: A Review of 15 Countries. International Water Management Institute, Colombo. https://doi.org/10.5337/2012.213

[21] United Nations Educational, Scientific and Cultural Organization (2006) The United Nations World Water Development Report 2: Case Study: Kenya-Kenya National Water Development Report. World Water Assessment Programme (WWAP). UNESCO, Paris.

[22] World Business Council for Sustainable Development (2006) Facts and Trends: Water. World Business Council for Sustainable Development, Geneva.

[23] Radar Technologies International (2013) Advanced Survey of Groundwater Resources of Northern and Central Turkana County, Kenya. Final Technical Report, Radar Technologies International, Nairobi.

[24] Kimani, A., Advani, R. and Sy, J. (2011) Financing Urban Water Services In Kenya: Utility Shadow Credit Ratings. Water and Sanitation Program. World Bank, Washington DC.

[25] Richards, T., Doering, E., D Souza, A., Lang, H., Plumm, H., Schaefer, D. and Werchota, R. (2008) Water Supply and Sanitation Sector Reforms in Kenya, Tanzania, Uganda and Zambia: Challenges and Lessons. GesellschaftfuerTechnischeZusammenarbeit (GTZ) GmbH, Dar es Salaam.

[26] Katui-Katua, M. (2004) Drawers of Water II: 30 Years of Change in Domestic Water Use \& Environmental Health in East Africa, Kenya Country Study. International Institute for Environment and Development (IIED), London.

[27] Cook, J., Kimuyu, P. and Whittington, D. (2016) The Costs of Coping with Poor Water Supply in Rural Kenya. Water Resources Research, 52, 841-859. https://doi.org/10.1002/2015WR017468

[28] Ministry of Water and Irrigation (2007) Water Sector Reform in Kenya and the Human Right to Water. Ministry of Water and Irrigation, Kenya.

[29] World Bank (2016) Kenya Urbanization Review (Report No. AUS8099). World Bank, Washington DC.

[30] Rampa, F. (2011) Analysing Governance in the Water Sector in Kenya (Discussion Paper No. 124). European Centre for Development Policy Management, Maastricht.

[31] Ministry of Water and Irrigation (2007) The Pro-Poor Implementation Plan for Water Supply and Sanitation. Ministry of Water and Irrigation, Nairobi.

[32] Kwena, R. and Makori, M. (2015) Determinants of Sustainability of Rural Water Projects in Kenya: A Case Study of the Netherlands Development Organisation (SNV) Supported Water Schemes in Kajiado County. Strategic Journal of Business \& Change Management, 124, 2025-2077. 
[33] Behrens-Shah, P. (2011) Sustainability of Water Supply Systems in Kenya-Ex Post Assessments of 100 Water Supply Systems Constructed/Rehabilitated by Welthungerhilfe between 2006-2009. Welthungerhilfe, Berlin.

[34] Harvey, P.A., Ikumi, P.N. and Mutethia, D.K. (2003) Sustainable Handpump Projects in Africa-Report on Fieldwork in Kenya: January 30-February 14 2003. Water, Engineering and Development Centre, Loughborough University, Leicestershire.

[35] Spaling, H., Brouwer, G. and Njoka, J. (2014) Factors Affecting the Sustainability of a Community Water Supply Project in Kenya. Development in Practice, 24, 797-811. https://doi.org/10.1080/09614524.2014.944485

[36] Water Services Regulatory Board (2015) Impact Issue No. 8, A Performance Review of Kenya's Water Services Sector 2013-2014. Water Services Regulatory Board, Nairobi.

[37] Institute of Economic Affairs (2007) A Rapid Assessment of Kenya's Water, Sanitation and Sewerage Framework. Institute of Economic Affairs, Nairobi.

[38] Acheampong, E.N., Swilling, M. and Urama, K. (2016) Sustainable Urban Water System Transitions through Management Reforms in Ghana. Water Resources Management, 30, 1835-1849. https://doi.org/10.1007/s11269-016-1256-3

[39] Water Services Regulatory Board and World Bank (2015) Kenya Water Service Provider Creditworthiness Index Report. WASREB/World Bank, Nairobi.

[40] Ministry of Water and Irrigation (2009) Integrated Water Resources Management and Water Efficiency Plan for Kenya. Republic of Kenya, Nairobi.

[41] World Bank (2006) Climate Variability and Water Resources Degradation in Kenya-Improving Water Resources Development and Management (Working Paper No. 69). World Bank, Washington D.C.

[42] Ministry of Water and Irrigation (2011) 2010 Annual Water Sector Review Report. Ministry of Water and Irrigation, Nairobi.

[43] Water Resources Management Authority (2015) Annual Water Resources Situation Report 2014-2015. Water Resources Management Authority, Nairobi.

[44] World Bank (2003) Kenya Water Resources Infrastructure Gaps (Working Paper No. 62098). World Bank, Washington DC.

[45] Nkonya, E., Gicheru, P., Woelcke, J., Okoba, B., Kilambya, D. and Gachimbi, L.N. (2006) Out of Site Out of Mind: Quantifying the Long-Term Off-Site Economic Impacts of Land Degradation in Kenya. American Agricultural Economics Association Annual Meeting, Long Beach, 23-26 July 2006, 21344.

[46] Marks, S.J. and Davis, J. (2012) Does User Participation Lead to Sense of Ownership for Rural Water Systems? Evidence from Kenya. World Development, 40, 1569-1576. https://doi.org/10.1016/j.worlddev.2012.03.011

[47] Ogendi, G.M. and Ong'oa, I.M. (2009) Water Policy, Accessibility and Water Ethics in Kenya. Santa Clara Journal of International Law, 7, 177-196.

[48] Olima, W.H.A. and K'Akumu, O.A. (1999) The Problems of Project Implementation: A Post-Mortem Study of Thika Dam Project, Kenya. Habitat International, 23, 467-479. https://doi.org/10.1016/S0197-3975(99)00021-1

[49] Gichuki, N.F. (2002) Water Scarcity and Conflicts: A Case Study of the Upper EwasoNg'iro North Basin. International Water Management Institute, Colombo.

[50] Koundouri, P., Pashardes, P., Swanson, T. and Xepapadeas, A. (2003) The Economics of Water Management in Developing Countries: Problems, Principles and Poli- 
cies (DEOS Working Papers 0303). Athens University of Economics and Business, Athens.

[51] Medema, W., McIntosh, B.S. and Jeffrey, P.J. (2008) From Premise to Practice: A Critical Assessment of Integrated Water Resources Management and Adaptive Management Approaches in the Water Sector. Ecology and Society, 13, 29. https://doi.org/10.5751/ES-02611-130229 